\title{
Loss of Heterozygosity Analysis of Chromosomes 9, 10 and 17 in Gliomas in Families
}

\author{
Christopher J. Watling, Donald J. van Meyel, David A. Ramsay, \\ David R. Macdonald and J. Gregory Cairncross
}

\begin{abstract}
Background: Studies of sporadic malignant gliomas have identified structural abnormalities in a number of chromosomal regions, especially losses of DNA on 9p, 10 and 17p. Purpose: We undertook the following molecular analysis in families with glioma to determine the frequency of chromosomal losses in these regions and to test the utility of microsatellite markers in demonstrating losses of heterozygosity. Methods: Genomic DNA was extracted from tumor tissue and venous blood from 20 patients with a family history of glioma. Dinucleotide repeat polymorphisms (microsatellites) were analyzed by polymerase chain reaction to assess loss of constitutional heterozygosity (LOH) on 9p, 10 and 17p. Three polymorphic markers on chromosome 9 (D9S104, D9S161, D9S165), one on chromosome 10 (D10S209), and two on 17p (D17S786, D17S796) were used. Autoradiographic films were analyzed for $\mathrm{LOH}$ after radioactively labelled polymerase chain reaction products were resolved on denaturing formamide-acrylamide gels. Results: Of 20 patients informative for at least one of three chromosome 9 markers, 12 (60\%) showed LOH at one or more loci; of 9 informative for the chromosome 10 marker, $4(44 \%)$ showed $\mathrm{LOH}$; and of 16 informative for at least one of two chromosome 17 markers, $7(44 \%)$ showed LOH at one or both loci. These LOH rates do not include instances of tumor nullizygosity $(0-35 \%)$ and therefore represent minimum frequencies of chromosomal losses at these loci. Conclusions: Microsatellite markers can be used to detect LOH in archival glioma tissue. As in sporadic gliomas, frequent LOH was observed on 9p (9p21-22), 10 and 17p, supporting the notion that these regions may harbour tumor suppressor genes important in glioma development. Further work will be required to determine whether the proportion of $\mathrm{LOH}$ in these chromosomal regions is higher in familial gliomas than sporadic ones, as might occur with an inherited suppressor gene conferring susceptibility to gliomas in families.
\end{abstract}

RÉSUMÉ: Étude des chromosomes 9,10 et 17 pour la perte d'hétérozigotie dans les familles porteuses de gliomes.

Introduction: Des étude de cas sporadiques de gliomes malins ont montré qu'il existe des anomalies structurales dans certaines régions chromosomiques, surtout des pertes d'ADN sur 9 p, 10 et 17p. But: Nous avons procédé à des analyses moléculaires dans des familles porteuses de gliomes afin de déterminer la fréquence des pertes chromosomiques dans ces régions et l'utilité de microsatellites comme marqueurs pour démontrer une perte d'hétérozygotie. Méthodes: Nous avons extrait l'ADN génomique de tissus tumoraux et de sang veineux de 20 patients ayant une histoire familiale de gliome. Nous avons analysé des polymorphismes constitués de séquences répétitives de dinucléotides (microsatellites) au moyen de la réaction en chaine de la polymérase (PCR) pour évaluer la perte d'hétérozygotie constitutionnelle (PDH) en 9p, 10 et 17p. Trois marqueurs polymorphiques sur le chromosome 9 (D9S104, D9S161, D9S165), un sur le chromosome 10 (D10S209), et deux sur 17p (D17S786, D17S796) ont été utilisés. Les produits de la réaction par PCR ont été marqués par un marqueur radioactif et séparés sur un gel de formamide-acrylamide dénaturant. Les films autoratiographiques ont étudiés pour détecter la présence de PDH. Résultats: Parmi les 10 patients qui étaient informatifs pour au moins un des trois marqueurs sur le chromosome 9, $12(60 \%)$ avaient une PDH à un ou plusieurs loci; 4 (44\%) de 9 patients informatifs pour le marqueur du chromosome 10 avaient une PDH; et $7(44 \%)$ de 16 patients informatifs pour au moins un des deux marqueurs du chromosome 17 avaient une PDH à un ou au deux loci. Ces fréquences de PDH n'incluent pas les cas de nullizygotie de la tumeur $(0-35 \%)$ et représentent donc des fréquences minimum de pertes chromosomales à ces loci. Conclusions: Les microsatellites peuvent être utilisés comme marqueurs pour détecter des PDH dans des tissus de gliomes archivés. Comme c'est le cas dans les gliomes sporadiques, nous avons observé des PDH fréquentes sur $9 p$ ( $9 p 21-22$ ), 10 et 17p, ce qui suggère que ces régions peuvent être le site de gènes suppresseurs de tumeurs qui sont importants dans le développement des gliomes. D'autres études seront nécessaires pour déterminer si la proportion de PDH dans ces régions chromosomiques est plus élevée dans les gliomes familiaux que dans les cas sporadiques, comme ce pourrait être le cas s'il existe un gène suppresseur conférant une susceptibilité au gliome dans ces familles.

Can. J. Neurol. Sci. 1995; 22: 17-21

Gliomas are the commonest primary brain tumors of adults. Most gliomas occur sporadically, but families with multiple affected members have been described.' The study of such families may lead to the isolation of susceptibility genes which predispose to glioma development. "Familial" gliomas are uncommon, but in one recent study, $6.7 \%$ of patients with newly diagnosed glial tumors gave a
From the Departments of Clinical Neurological Sciences (C.J.W., D.A.R.. D.R.M. J.G.C.), Microbiology and Immunology (D.J.vM., J.G.C.). Oncology (D.J.vM., D.R.M. J.G.C.) and Pathology (D.A.R.), the University of Western Ontario and the London Regional Cancer Centre, London.

RECEIVED JULY 27, 1994. ACCEPTED IN FINAL FORM SEPTEMBER 19, 1994.

Reprint requests to: Dr. J. Gregory Cairncross, London Regional Cancer Centre, 790 Commissioners Road East, London, Ontario, Canada N6A 4L6 
positive and verifiable family history of glioma. ${ }^{1}$ An understanding of the genetic mechanisms underlying the development of these seemingly familial cases may prove equally relevant to sporadically occurring gliomas, since sporadic cancers generally arise as a result of the same genetic alterations which occur in their inherited counterparts. $^{2}$

Most cancers, including glioma, occur as a result of a multistep process involving the accumulation of genetic mutations at critical loci, which cause activation of oncogenes and inactivation of tumor suppressor genes. ${ }^{3}$ While oncogenes are growth-promoting, tumor suppressor genes function to constrain cell growth and play a role in the normal processes of tissue differentiation and cell death. ${ }^{4}$ Loss of a normal tumor suppressor allele usually involves the loss of neighbouring chromosomal regions as well, so that the consistent observation in tumors of loss of heterozygosity ( $\mathrm{LOH}$ ) for a particular chromosomal marker implies the presence of a closely mapping tumor suppressor gene that is involved in the genesis of that tumor. ${ }^{4}$ $\mathrm{LOH}$ at non-random frequency has been consistently reported at a number of different loci in sporadic gliomas, especially $9 p, 5,610,7,8$ and $17 \mathrm{p},{ }^{9-13}$ suggesting that the inactivation of multiple tumor suppressor genes located in these regions may play a role in glioma development. Of particular interest is region 9p21, the site of a putative tumor suppressor gene involved in the development of many cancers, including gliomas. ${ }^{14}$

Demonstration of LOH in gliomas has generally involved conventional Southern blotting and hybridization techniques. A newer method utilizing microsatellite markers and the polymerase chain reaction (PCR) is now available. Microsatellites are highly polymorphic simple sequence repeats distributed widely throughout the human genome. ${ }^{15}$ Their abundance, polymorphous nature, and amenability to PCR have made them extremely useful in genetic studies. The PCR-based technique offers the additional advantages of being faster and consuming less DNA than conventional blotting and hybridization. ${ }^{15}$ The goals of this study were to determine $\mathrm{LOH}$ frequencies in regions thought to harbour tumor suppressor genes relevant to gliomas, to ascertain whether certain losses were more common in "familial" than sporadic gliomas, and to test the applicability of microsatellite markers to this type of analysis.

\section{Materials and Methods}

\section{Patients and tissue samples}

Twenty glioma patients (14 males, six females) with a family history of glioma and on whom both blood and tumor tissue were readily available were chosen for this study. These 20 patients were drawn from 17 families, 12 of which have been reported previously.' Among these 17 families, the relationships between affected members were first degree in six, second degree in 10 , and third degree in one. Our 20 study patients included three pairs of related individuals; the remaining 14 patients were unrelated probands. The tumor types included seven glioblastomas, three anaplastic astrocytomas, three mixed gliomas, three oligodendrogliomas, two astrocytomas, one ganglioglioma, and one primitive neuroglial tumor. In nine patients, tumor samples were obtained at the time of surgery and in eight of these the samples were frozen for periods of one to nine years prior to analysis. In the remaining 11 patients, archival paraffin-embedded tumor tissue from pathology specimens was used. For all 20 patients, peripheral venous blood was used as the source of normal genomic DNA.

\section{DNA isolation}

Frozen tumor samples were minced with a scalpel, suspended in digestion buffer ( $75 \mathrm{mM}$ sodium chloride, $24 \mathrm{mM}$ EDTA), and ground to a single-cell suspension using a manual homogenizer. Proteinase $\mathrm{K}(200 \mu \mathrm{g} / \mathrm{ml})$ and sodium dodecyl sulphate $(0.5 \%)$ were then added and the samples incubated overnight at $42^{\circ} \mathrm{C}$ on a rotating platform shaker. After treatment at $60^{\circ} \mathrm{C}$ for 1 hour, the samples were extracted once with an equal volume of phenol, once with a 50:50 mixture of phenol and chloroform, and once with chloroform. Ethanol precipitation of DNA was followed by resuspension in a $100 \mathrm{mM}$ Tris- $\mathrm{Cl}$ (pH 7.5), $10 \mathrm{mM}$ EDTA solution containing 50 $\mu \mathrm{g} / \mathrm{ml}$ ribonuclease A. Samples were then incubated for 2 hours at $37^{\circ} \mathrm{C}$, extracted with phenol and chloroform, and precipitated with ethanol. Paraffin-embedded samples were first treated with xylene then washed twice with ethanol prior to digestion with proteinase $K$ as above.

Venous blood was centrifuged and the pellet incubated with 5 volumes of pre-warmed ammonium chloride $(140 \mathrm{mM})$ : Tris (17 $\mathrm{mM}$ ) solution at $37^{\circ} \mathrm{C}$ for 15 minutes. Samples were centrifuged again and the pellets were rinsed twice with phosphate buffered saline then digested and treated as above with the exception of the ribonuclease treatment.

\section{Polymerase chain reactions}

The following microsatellite markers were used: D9S104, D9S161, and D9S165 on 9p21-22, D10S209 on 10q24-26, and D17S786 and D17S796 on 17p13.1 (Research Genetics, Huntsville, Alabama). The forward primer of each marker pair was endlabelled with $\left[\gamma^{32} \mathrm{P}\right]$ dATP using T4 polynucleotide kinase (Gibco BRL, Gaithersburg, Maryland). Each $25 \mu$ polymerase chain reaction (PCR) contained up to $50 \mathrm{ng}$ of DNA, $200 \mu \mathrm{mol}$ of each deoxynucleotide triphosphate, 0.625 units of Taq polymerase, and $0.32 \mu \mathrm{mol}$ of each primer in $1 \mathrm{mM}$ magnesium chloride, $10 \mathrm{mM}$ HEPES, and $50 \mathrm{mM}$ potassium chloride. Less than $50 \mathrm{ng}$ of DNA was used in 5 of the 20 normal samples and 5 of the 20 tumor samples because the amounts of DNA isolated were too small to permit the use of higher concentrations. Thermal cycling entailed an initial denaturation at $87^{\circ} \mathrm{C}$ for 7 minutes followed by 30 cycles of denaturation $\left(92^{\circ} \mathrm{C}, 1\right.$ minute), annealing $\left(50^{\circ} \mathrm{C}, 2\right.$ minutes) and extension $\left(72^{\circ} \mathrm{C}, 1\right.$ minute), with a final $72^{\circ} \mathrm{C}$ extension for 7 minutes. When products of these reactions did not produce intense bands on autoradiography, reactions were repeated with the amount of DNA template tripled (up to $150 \mathrm{ng}$ ) to improve yield.

\section{Electrophoresis and autoradiography}

PCR products were denatured at $94^{\circ} \mathrm{C}$ for 3 minutes then resolved on formamide-acrylamide gels ( $8 \%$ acrylamide, $32 \%$ formamide, $5.6 \mathrm{M}$ urea in $1 \mathrm{X}$ Tris borate EDTA buffer) as described by Litt et al. ${ }^{16} \mathrm{Gels}$ were subjected to autoradiography with exposure times of $16-96$ hours. Autoradiographs were examined visually for LOH. If necessary, scanning densitometry was used to confirm the result. Allelic loss was presumed when the ratio of the intensity of one of the tumor alleles to its corresponding normal allele was less than $50 \%$ of the ratio of the intensities of the other allele pair.

\section{Results}

Results are summarized in the Table, with representative autoradiographs shown in the Figure. Samples whose PCR product for a 
Table. Summary of microsatellite results and pathology of twenty familial gliomas.

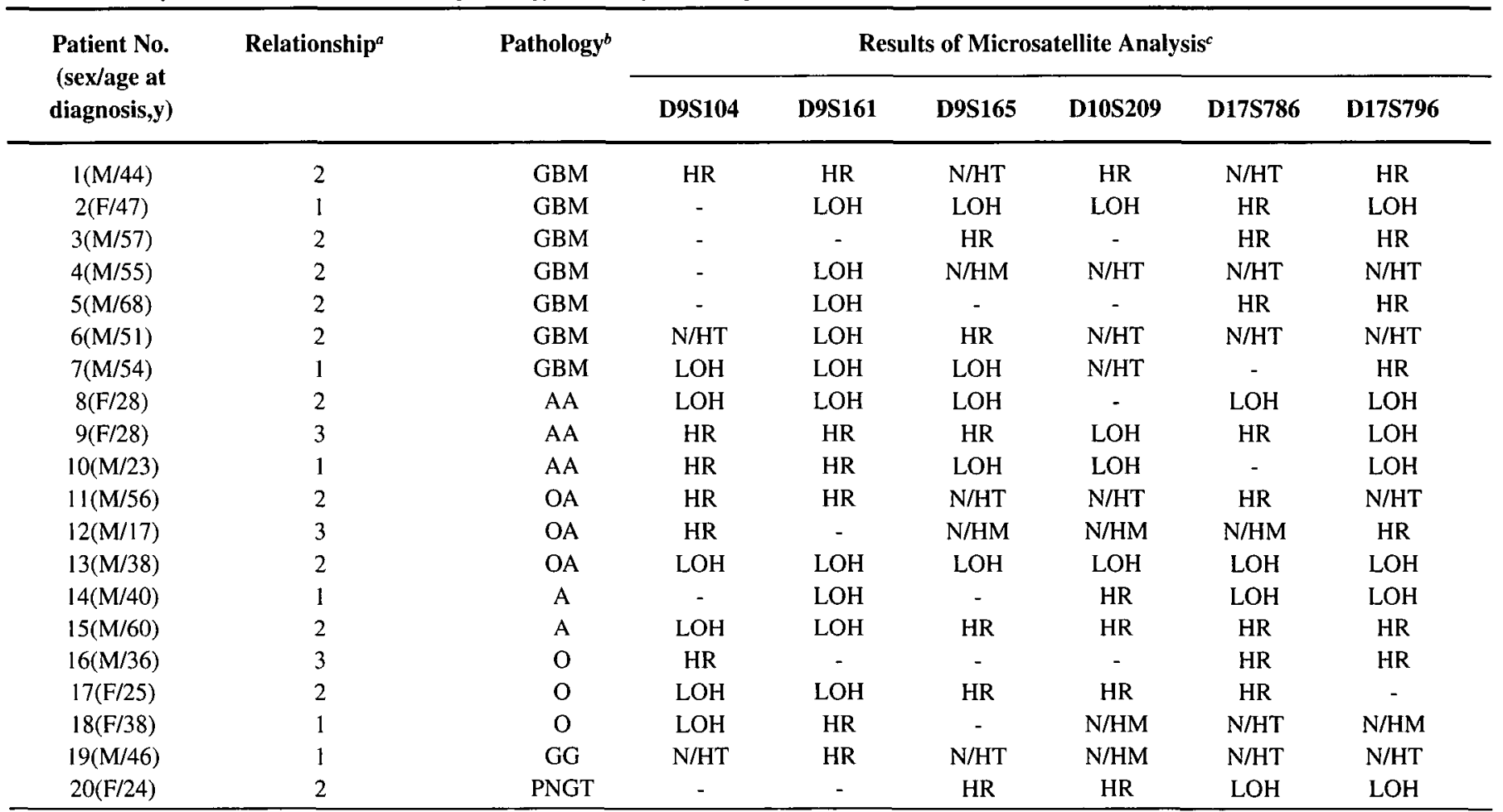

${ }^{a}$ Degree of relationship between study patient and closest glioma-affected relative. $1=$ first degree, $2=$ second degree, etc.

${ }^{b} \mathrm{GBM}=$ glioblastoma, $\mathrm{AA}=-$ anaplastic astrocytoma, $\mathrm{OA}=$ oligoastrocytoma, $\mathrm{A}=$ astrocytoma, $\mathrm{O}=$ oligodendroglioma, $\mathrm{GG}=$ ganglioglioma, $\mathrm{PNGT}=$ primitive neuroglial tumor.

${ }^{c} \mathrm{LOH}=$ loss of heterozygosity, $\mathrm{HR}=$ heterozygosity retained, N/HT $=$ nullizygous tumor from heterozygous patient, $\mathrm{N} / \mathrm{HM}=$ nullizygous tumor from homozygous patient, - = non informative.

particular marker produced no bands when resolved electrophoretically were classified nullizygous.

\section{Chromosome 9}

Of 12 cases informative for marker D9S104, six (50\%) showed LOH. Of the eight remaining cases, six were non-informative due to constitutional homozygosity and two showed heterozygosity for blood and nullizygosity for tumor DNA. Of 16 cases informative for marker D9S161, 10 (62.5\%) showed LOH. All four remaining cases were non-informative due to constitutional homozygosity. Of 11 cases informative for marker D9S165, five (55\%) showed LOH. Of the nine remaining cases, four were non-informative due to constitutional homozygosity, three showed heterozygosity for blood and nullizygosity for tumor DNA, and two showed homozygosity for blood and nullizygosity for tumor DNA. Overall, 20 patients were informative for at least one of the three chromosome 9 markers examined and $12(60 \%)$ showed LOH at one or more loci.

\section{Chromosome 10}

Of nine cases informative for marker DI0S209, four (44\%) showed LOH. Of the 11 remaining cases, four were non-informative due to constitutional homozygosity, four showed heterozygosity for blood and nullizygosity for tumor DNA, and three showed homozygosity for blood and nullizygosity for tumor DNA.

\section{Chromosome 17}

Of 12 cases informative for marker D17S786, four (33\%) showed LOH. Of the eight remaining cases, two were non-informative due to constitutional homozygosity, five showed heterozygosity for blood and nullizygosity for tumor DNA, and one showed homozygosity for blood and nullizygosity for tumor DNA. Of 14 cases informative for marker DI7S796, seven (50\%) showed LOH. Of the six remaining cases, one was non-informative due to constitutional homozygosity, four showed heterozygosity for blood and nullizygosity for tumor DNA, and one showed homozygosity for blood and nullizygosity for tumor DNA. Overall, 16 patients were informative for at least one of the two chromosome 17 markers examined and seven (44\%) showed $\mathrm{LOH}$ at one or both loci.

\section{Discussion}

Substantial LOH rates were observed on chromosomes 9p, 10q, and $17 \mathrm{p}$ in "familial" gliomas, in keeping with the view that glioma development involves a series of genetic alterations occurring at multiple chromosomal loci. ${ }^{17}$ The highest LOH frequency was noted for the three chromosome 9 markers, all of which localize to 9 p21-22. ${ }^{18,19} \mathrm{LOH}$ in this region was observed in all tumor grades (five of seven glioblastomas, two of three anaplastic astrocytomas, two of two astrocytomas), suggesting that 9p21-22 loss may be an early event in tumor development, though the number of cases in each tumor grade is small. Previous studies have demonstrated frequent DNA losses at 9p22, a region containing the interferon gene cluster. ${ }^{5,6}$ Miyakoshi and colleagues reported genetic alterations in the IFNA-IFNB region in 10 of 19 malignant glioma cell lines, ${ }^{20}$ while James et al. showed that homozygous deletions in glioma cell lines on $9 p$ were limited to a small region which includes most of the IFNA gene cluster. ${ }^{21}$ These data have led many to suggest that either the interferon class of genes themselves or another closely linked gene may function as a tumor suppressor whose inactivation is important in the progression of gliomas. ${ }^{56,20-22}$ More recent studies 


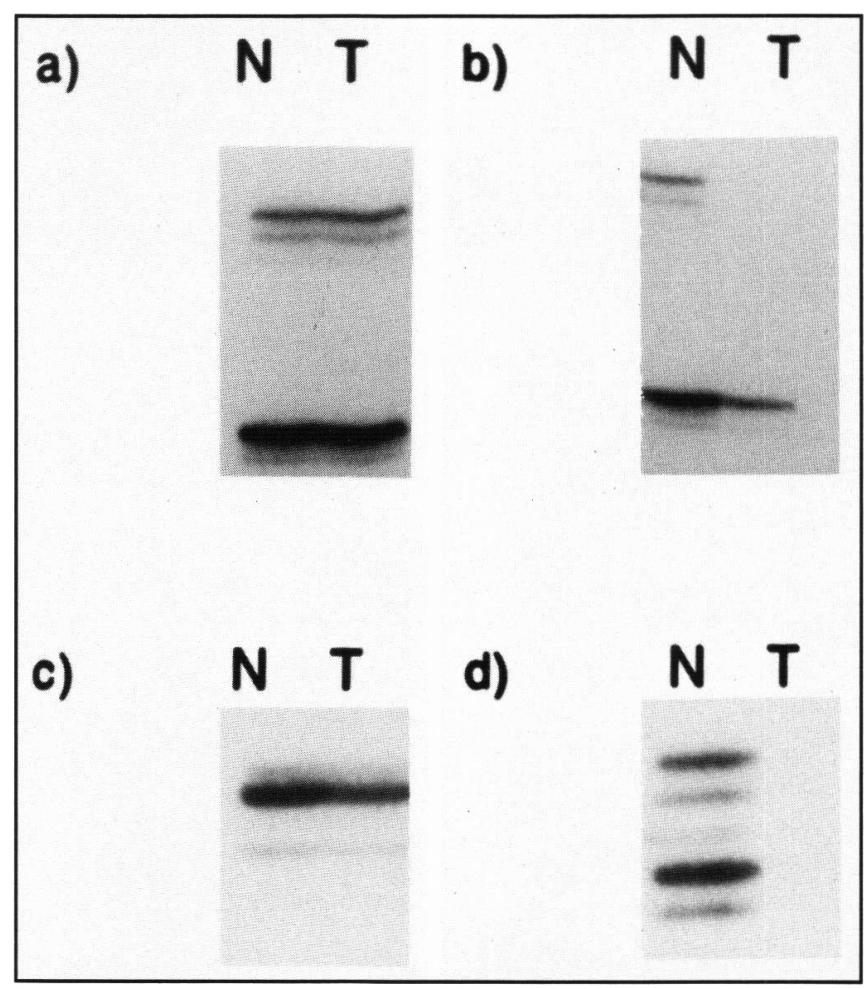

Figure: Autoradiographs showing paired normal and tumor specimens from selected patients $(N=$ normal, $T=$ tumor): a) Retention of heterozygosity at D17S796 - note two intense bands representing two alleles at this locus for each sample. The less intense bands which appear immediately below each strong band are "shadow bands", an artifact characteristic of microsatellite analysis. ${ }^{16}$ b) LOH at D17S796 - note two normal alleles but only one tumor allele, indicating loss of one allele by this tumor. c) Non-informative sample at D9S161 - note a single normal allele, indicating constitutional homozygosity and preventing classification of the status of this tumor. d) Tumor nullizygosity with a heterozygous normal sample at D17S786 - note two normal alleles but no tumor alleles.

of cell lines derived from multiple types of human cancer, including glioma, have shown frequent deletions of a region of $9 \mathrm{p} 21$ which contains a gene encoding an inhibitor (p16) of cyclin-dependent kinase 4 , an enzyme that normally stimulates cell division. ${ }^{14,23}$ These data suggest that p16 may be an important tumor suppressor, though deletions of the $\mathrm{p} 16$ gene remain to be demonstrated in primary tumor samples. Our $60 \%$ LOH frequency at $9 \mathrm{p} 21-22$ supports the notion that a tumor suppressor gene is contained in this area and provides further justification for a more detailed study of this region.

LOH for loci on chromosome 10 has generally been associated with glioblastoma pathology, not with astrocytic gliomas of lower grade. ${ }^{78}$ In our study, $\mathrm{LOH}$ was observed in higher grade gliomas only (one of two informative glioblastomas, with three others showing nullizygosity, and two of two informative anaplastic astrocytomas), and not in low grade astrocytomas. Pershouse et al. introduced a copy of chromosome 10 into a human glioma cell line and demonstrated suppression of the tumorigenic phenotype in the hybrid clones in vitro and in vivo, suggesting that chromosome 10 also contains a tumor suppressor gene whose inactivation is required for glioma progression. ${ }^{24}$

LOH for loci on $17 \mathrm{p}$ is a frequent observation in glial tumors of all histologic grades, suggesting the presence of a tumor suppressor gene whose inactivation is an early event in glioma development.9-13 Consistent with this hypothesis, we found $\mathrm{LOH}$ at this locus in all tumor grades (one of seven glioblastomas, with three others showing nullizygosity for one or both markers, three of three anaplastic astrocytomas, and one of two astrocytomas). The two microsatellite markers on chromosome 17 used in this analysis map near $17 \mathrm{p} 13.1 .^{18}$ This the site of the tumor suppressor gene $\mathrm{p} 53$ whose inactivation appears to be an important step in the oncogenesis of many human tumors, including glioma. In some tumors, deletion of one copy of the p53 gene is accompanied by mutations in the remaining allele which render the gene product inactive. ${ }^{11.25}$

One of the challenges we encountered interpreting these data was the frequent occurrence of tumor nullizygosity - $10 \%$ for D9S104, 25\% for D9S165, 35\% for D10S209, 30\% for D17S786, and $25 \%$ for D17S796. In all, nine tumors showed nullizygosity for at least one of the six loci examined. Of these nine tumors, DNA had been extracted from archival paraffin-embedded tissue in seven and from previously frozen gross tumor specimens in two. Because the yield of DNA was often low from small archival samples, it is possible that nullizygosity represents a technical problem due to low DNA concentration in the PCR mixture, and hence the failure of these DNA samples to amplify at these loci. However, none of the seven DNA samples derived from archival tissue was nullizygous for all six loci and the two DNA samples extracted from gross tumor specimens, where recovery of DNA was substantial, also demonstrated nullizygosity at one or more loci. These findings suggest that tumor nullizygosity may in at least some instances represent a true and important finding rather than a technical artifact. Some of these gliomas may have deletions of both alleles at these loci; such homozygous deletions have been described. ${ }^{5.6 .21}$ Interestingly, six of the nine tumors showing nullizygosity were high grade anaplastic astrocytomas or glioblastomas, suggesting a relationship between malignant tumor pathology and more extensive deletions. The $\mathrm{LOH}$ frequencies reported here do not take instances of tumor nullizygosity into account, and therefore may underestimate the true frequency of genetic alterations in these tumors at these loci.

Certain individuals may be genetically predisposed to glioma, inheriting mutations in one or more of the genes responsible for glioma development. The finding of a significantly higher $\mathrm{LOH}$ rate for a particular chromosomal region in "familial" gliomas, or similar $\mathrm{LOH}$ patterns among related individuals, would support the notion of inherited susceptibility to glioma. The frequencies of LOH reported here are similar to those in previous studies of sporadic gliomas, ${ }^{5-13}$ though the use of microsatellite markers rather than restriction fragment length polymorphisms makes direct comparisons difficult. In most of our cases, only the proband of an affected family was treated at this centre, and opportunities to study tissue from related individuals have been limited thus far. Among the three pairs of related individuals in this study were one pair of second degree relatives (patients 6 and 17) and two pairs of third degree relatives (patients 5 and 16, patients 12 and 15). For each related pair, there were two markers for which both individuals were informative (excluding instances of nullizygosity), and in two of the three pairs the $\mathrm{LOH}$ patterns were the same for these two markers while in the third pair the pattern was the same for only one of the two markers. Any conclusion for or against a genetic basis for gliomas in families is premature given these limited data, but our results certainly support the need for further study of related affected individuals. 
Finally, this study has demonstrated the usefulness of microsatellite markers in LOH analysis. Their amenability to PCR amplification makes it possible to undertake molecular analysis even when only small amounts of DNA are available, so that this technique can be applied to both fresh and archival tissue. As more of these highly polymorphic markers are accurately mapped, they will become increasingly valuable in determining the locations of genes involved in the development of gliomas and other cancers.

\section{REFERENCES}

1. Ikizler Y, van Meyel DJ, Ramsay DA, et al. Gliomas in families. Can J Neurol Sci 1992; 19: 492-497.

2. Eng $\mathrm{C}$, Ponder BAJ. The role of gene mutations in the genesis of familial cancers. FASEB J 1993; 7: 910-919.

3. Rasheed BKA, Bigner SH. Genetic alterations in glioma and medulloblastoma. Cancer Metastasis Rev 1991; 10: 289-299.

4. Weinberg RA. Tumor suppressor genes. Science 1991; 254: 1138-1146.

5. Olopade OI, Jenkins RB, Ransom DT, et al. Molecular analysis of deletions of the short arm of chromosome 9 in human gliomas. Cancer Res 1992; 52: 2523-2529.

6. James $\mathrm{CD}, \mathrm{He} \mathrm{J}$, Carlbom E, et al. Chromosome 9 deletion mapping reveals interferon alpha and interferon beta- 1 gene deletions in human glial tumors. Cancer Res 1991; 51: 1684-1688.

7. Watanabe K, Nagai M, Wakai S, et al. Loss of constitutional heterozygosity in chromosome 10 in human glioblastoma. Acta Neuropathol 1990; 80: 251-254.

8. James CD, Carlbom E, Damanski JP, et al. Clonal genomic alterations in glioma malignancy stages. Cancer Res 1988; 48: 5546-5551.

9. James CD, Carlbom E, Nordenskjold M, et al. Mitotic recombination of chromosome 17 in astrocytomas. Proc Natl Acad Sci USA 1989; 86: $2858-2862$.

10. Fults D, Tippets RH, Thomas GA, et al. Loss of heterozygosity for loci on chromosome $17 \mathrm{p}$ in human malignant astrocytoma. Cancer Res 1989; 49: 6572-6577.

11. Fults D, Brockmeyer D, Tullous MW, et al. p53 mutation and loss of heterozygosity on chromosomes 17 and 10 during human astrocytoma progression. Cancer Res 1992; 52: 674-679.
12. von Deimling A, Eibl RH, Ohgaki $\mathrm{H}$, et al. p53 mutations are associated with $17 \mathrm{p}$ allelic loss in grade II and grade III astrocytoma. Cancer Res 1992; 52: 2987-2990.

13. El-Azouzi M, Chung RY, Farmer GE, et al. Loss of distinct regions on the short arm of chromosome 17 associated with tumorigenesis of human astrocytomas. Proc Natl Acad Sci USA 1989; 86: 7186-7190.

14. Kamb A, Gruis NA, Weaver-Feldhaus J, et al. A cell cycle regulator potentially involved in genesis of many tumor types. Science 1994; 264: 436-440.

15. Weber JL, May PE. Abundant class of human DNA polymorphisms which can be typed using the polymerase chain reaction. Am J Hum Genet 1989; 44: 388-396.

16. Litt M, Hauge X, Sharma V. Shadow bands seen when typing polymorphic dinucleotide repeats: some causes and cures. BioTechniques 1993; 15(2): 280-284.

17. Collins VP, James CD. Gene and chromosomal alterations associated with the development of human gliomas. FASEB J 1993; 7: 926-930.

18. Weissenbach J, Gyapay G, Dib C, et al. A second-generation linkage map of the human genome. Nature 1992; 359: 794-801.

19. NIH/CEPH Collaborative Mapping Group. A comprehensive genetic linkage map of the human genome. Science 1992; 258: 67-86.

20. Miyakoshi J, Dobler KD, Allalunis-Turner J, et al. Absence of IFNA and IFNB genes from human malignant glioma cell lines and lack of correlation with cellular sensitivity to interferons. Cancer Res 1990; 50: $278-283$.

21. James CD, He J, Collins VP, et al. Localization of chromosome 9p homozygous deletions in glioma cell lines with markers constituting a continuous linkage group. Cancer Res 1993; 53: 3674-3676.

22. Olopade OI, Bahlander SK, Pomykala H, et al. Mapping of the shortest region of overlap of deletions of the short arm of chromosome 9 associated with human neoplasia. Genomics 1992; 14: 437-443.

23. Nobori T, Miura K, Wu DJ, et al. Deletions of the cyclin-dependent kinase-4 inhibitor gene in multiple human cancers. Nature 1994; 368: 753-756.

24. Pershouse MA, Stubblefield E, Hadi A, et al. Analysis of the functional role of chromosome 10 loss in human glioblastomas. Cancer Res 1993; 53(20): 5043-5050.

25. Nigro JM, Baker SJ, Preisinger AC, et al. Mutations in the p53 gene occur in diverse human tumor types. Nature 1989; 342 : 705-708. 